\title{
Cell ordering
}

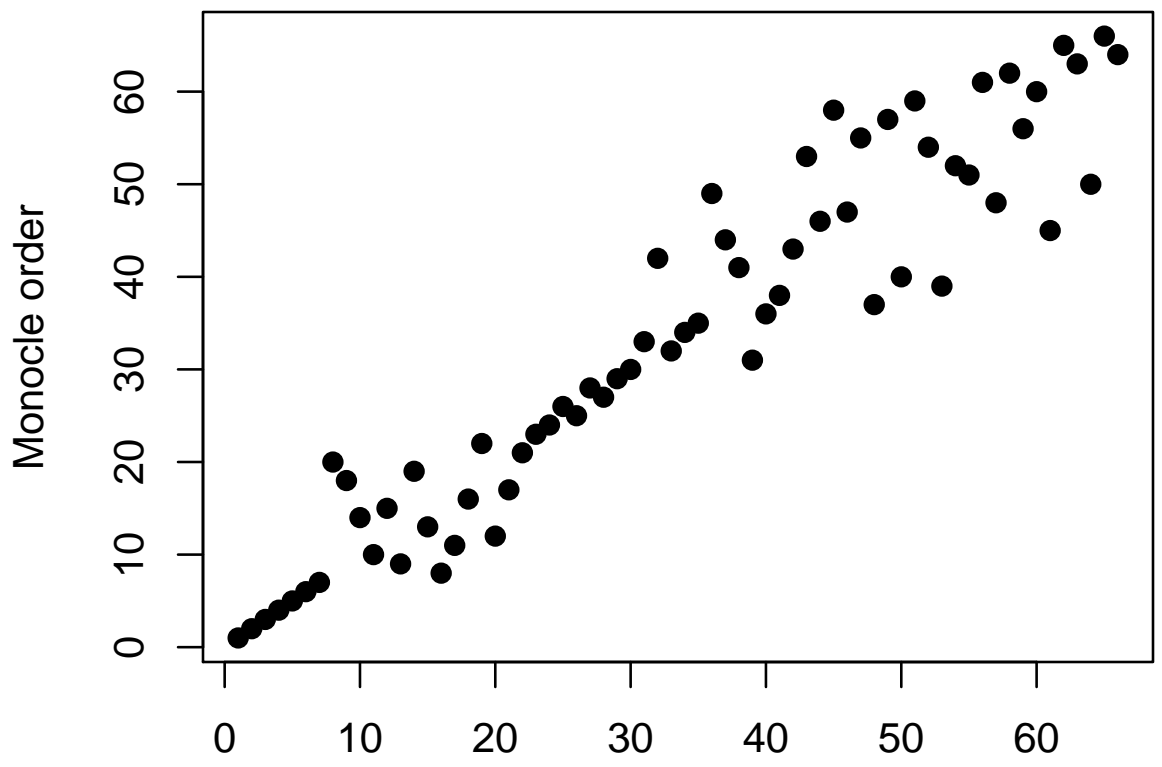

WaveCrest order 